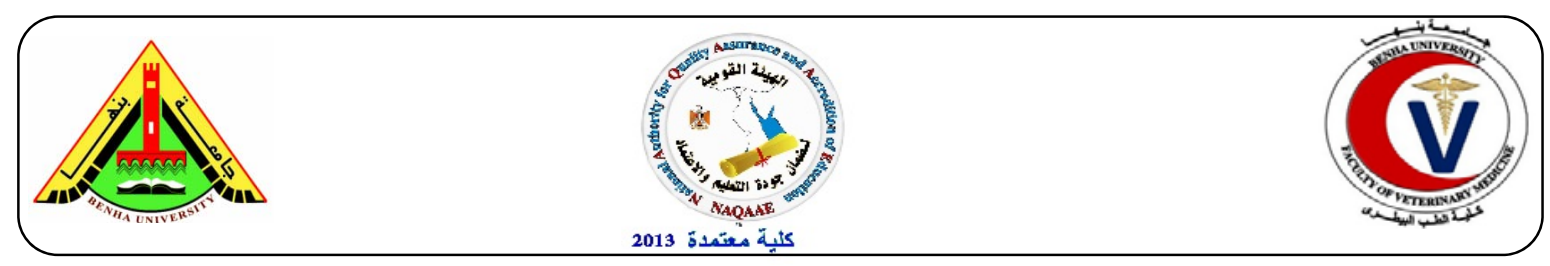

\title{
Biochemical Study on antioxidant after High Effort
}

\author{
Abdel-Maksoud A. Hussien ${ }^{1}$, Mohammed A. Hussein ${ }^{2}$, Naglaa Abd El-KhalikGobba ${ }^{3}$, Mahmoud \\ Rabie Ahmed ${ }^{1}$ \\ ${ }^{1}$ Department of Biochemistry, Faculty of Veterinary Medicine, Benha University, 13736 Moshtohor, \\ Qalioubeya, Egypt, ${ }^{2}$ Biochemistry Department, Faculty of Pharmacy, October 6th University, October \\ 6th city, Egypt, ${ }^{3}$ Department of Pharmacology, Faculty of Pharmacy, Misr University for Science and \\ Technology (MUST), October 6th City, Egypt.
}

\section{A B S T R A C T}

The present study was designed to evaluate hepatoprotective effects of Cranberry extract (75 and $150 \mathrm{mg} / \mathrm{kg} . \mathrm{b} . \mathrm{w})$ against Diclofenac sodium induced liver toxicity in rats. Oral administration of Diclofenac sodium $(150 \mathrm{mg} / \mathrm{kg}$. b.w.) led to significant increase in plasma Transaminases (L-Alanine and L-Aspartate), Lactate dehydrogenase (LDH), Alkaline phosphatase (ALP), Tumor Nicroses Factor-Alfa (TNF- $\alpha$ ), Nitric oxide (NO) and TBARS as well as plasma, Triacylglycerol, Total Cholesterol, and LDLCholesterol. Also, treatment of rats with Diclofenac sodium led to significant decrease in liver GSH, Protein Thiols (Pr-SHs), Superoxide Dismutase (SOD), Catalase (CAT) as well as plasma HDL. The obtained result revealed that cranberry extract $(75$ and $150 \mathrm{mg} / \mathrm{kg}$.b.w.) prevent liver tissue damage through increasing of GSH, SOD and CAT activities and decrease significantly TBARs level. These results suggest that, cranberry may be effective in enhances the protection of heart toxicity by its radical scavenging effect and antioxidant activity.

Keywords: Diclofenac sodium, liver toxicity, cranberry, Antioxidant enzymes, lipid profile, GSH.

(http://www.bvmj.bu.edu.eg)

(BVMJ-30(1): 358-367, 2016)

\section{INTRODUCTION}

$\mathrm{N}$ on-Steroidal Anti-inflammatory Drugs (NSAIDs), as pro-oxidants, tissue date dissue damage such as gastrointestinal damage, nephrotoxicity and hepatotoxicity. There is evidence that oxidative stress is involved in these toxicities (Cantoni et al., 2003). The mechanism by which NSAIDs cause injury to the gastric mucosa is mainly due to the inhibition of cyclooxygenase enzyme (COX) and suppression of prostaglandin-mediated effects on mucosal protection (Wallace et al., 2000). Diclofenac, however, induces liver damage through various mechanisms such as mitochondrial permeability transition, (Masubuchi and Horie et al., 2001) activation of cytochrome P450 (Cantoni et al., 2003) in addition to generation of ROS
(Gomez-Lechon et al., 2003). A number of in vitro animal models have been used to investigate the possible mechanisms of NSAID-related hepatotoxicity. Studies using rat liver mitochondria and freshly isolated rat hepatocytes showed that diphenylamine, which is common in the structure of NSAIDs, uncouples oxidative phosphorylation, decreases hepatic ATP content and induces hepatocyte injury (Masubuchi et al., 2000). Furthermore, diclofenac is more toxic to drugmetabolizing than to non-metabolizing cell lines. The in vitro cytotoxicity correlated well with the formation of 5hydroxydiclofenac and particularly with the 5-dihydroxydiclofenac metabolite; the latter in particular can inhibit ATP synthesis. 
Cranberry is the best source of flavonols among 30 flavonol-containing plant foods studied (Aherne and O'Brien, 2002), and the flavonol content of cranberry is almost twice as high as 12 other commonly consumed fruit juices, including pomegranate and grape (Mullen et al., 2007). Quercetin is the most abundant flavonol in cranberry, and it varies from 11 to $25 \mathrm{mg} / 100 \mathrm{~g}$, primarily as the 3-ogalactoside (Vvedenskaya et al., 2004). Cranberry is also the best source of quercetin (Manach et al., 2004). Myricetin is the second most abundant flavonol, followed by kaempferol (Manach et al., 2004 and Vedenskaya et al., 2004). These compounds are yellow in color, and there are 20 different flavonol glycosides in cranberry, as confirmed by another article (Mullen et al., 2007). No reports about antioxidant of cranberry extract against Diclofenac sodium induced liver toxicity in rats. As a continuation of our interested research in pharmaceutical and medical importance of natural products (Hussein et al., 2014). We report herein, a facile route to explain antioxidant and hepatoprotective effects of cranberry extract in rat's model of diclofenac sodium -induced liver toxicity.

\section{MATERIAL AND METHODS}

2.1. Diclofenac sodium (100\%) and (Vitamin C, 100\%) were obtained from Merck Ltd., Germany.

All reagents used were of analytical grade and were obtained commercially.

\subsection{Experimental set up}

This experiment was carried out to examine the prophylactic potential of cranberry against Diclofenac sodium induced liver and renal toxicity in- vivo. Groups of animals each consisting of 10 rats were treated daily for 21 days as follows.

Group I: Normal; was given saline orally for 21 days.

Group II: Positive control; was treated with Diclofenac sodium (150mg/kg b.w.) suspended in saline orally in a single daily dose for 21 days (Boshra and Hussein, 2104).

Group III: was treated with Cranberry extract $(75 \mathrm{mg} / \mathrm{kg}$.b.w. orally $)+$ diclofenac sodium $(150 \mathrm{mg} / \mathrm{kg}$. b.w., orally) suspended in saline for 21 days (Abdel-Maksoud, et al., 2015).

Group IV: was treated with Cranberry extract $\quad(150 \mathrm{mg} / \mathrm{kg}$. b.w. orally $)+$ diclofenac sodium $(150 \mathrm{mg} / \mathrm{kg} . b . w . ~ o r a l l y)$ suspended in saline for 21 days (AbdelMaksoud, et al., 2015)

Group V: Was treated with Diclofenac sodium $(150 \mathrm{mg} / \mathrm{kg}$, orally) + Vitamin C $(1 \mathrm{~g} / \mathrm{kg} \mathrm{b.w}$. orally) in a single daily dose for 21 days (Luo et al., 1995).

\subsection{Blood samples:}

Blood samples were collected from the liver at the end of experimental period in dry, clean, and screw capped tubes, also, plasma was separated by centrifugation at 2500r.p.m for 15 minutes. Serum was separated by automatic pipette and received in dry sterile samples tube and kept in a deep freeze at $-20{ }^{\circ} \mathrm{C}$ until used for subsequent biochemical analysis.

\subsection{Tissue specimen (liver tissue):}

At the end of the experiment, rats of each group were sacrificed by cervical decapitation. The abdomen and chest were opened and the liver specimen was quickly removed and opened gently using a scrapper, cleaned by rinsing with ice-cold isotonic saline to remove any blood cells, clots, then blotted between 2 filter papers and quickly stored in a deep freezer at (-20 ${ }^{\circ} \mathrm{C}$ ) for subsequent biochemical estimation of plasma and liver transaminases (Lalanine and L-aspartate) (Reitman and Frankel, 1957), alkaline phosphatase (Kind and King 1954), GSH (Chanarin, 1989), superoxide dismutase (SOD) (Marklund and Marklund, 1974), catalase (CAT) (Sinha, 1972) and TBARS (Nichans and Samulelson, 1968) as well as plasma TNF$\alpha$ (Beyaert and Fiers, 1998), Nitric oxide (Miranda et al., 2001), protein thiols 
(Koster, et al., 1986), total protein (Weichselbaum, 1946), triglyceride[28], total cholesterol (Fossati and Prencipe 1982), HDL-C (Allain, et al., 1974) and LDL-cholesterol (Burnstein et al., 1970).

\subsection{Statistical analysis}

The obtained data were analyzed and graphically represented using the statistical package for social science (SPSS, 19.0 software), for obtaining mean and standard deviation of mean. The data were analyzed using one-way ANOVA to determine the statistical significance of differences among groups. Duncan's test was used for making a multiple comparisons among the groups for testing the inter-grouping homogeneity Steel et al., (1997).

\section{RESULTS}

After treatment with Diclofenac sodium, level of plasma ALT, AST and ALP were significantly $(P<0.01)$ increased compared to the control (table 1). Rat receiving extract of any of the two doses of cranberry extract used in this study (75 and $150 \mathrm{mg} / \mathrm{kg}$. b.w.) showed a significant decrease the plasma marker of liver enzymes $(\mathrm{P}<0.01)$. Also, supplementation of vitamin $\mathrm{C}$ at (1g/k.g.b.w.) resulted in a significant decrease in plasma ALT, AST and ALP compared to the group that received $(p<$ 0.01). Table 2 showed that oral administration of Diclofenac sodium at $150 \mathrm{mg} / \mathrm{kg}$.b.w. Resulted in a significant increase in plasma tumor necroses factor $-\alpha$ (TNF- $\alpha$ ), nitric oxide (NO) and thiobarbaturic acid reactive substances (TBARS) compared to the normal control group $(p<0.01)$. Rat receiving extract of any of the two doses of cranberry extract used in this study (75 and $150 \mathrm{mg} / \mathrm{kg}$.b.w.) showed a significant decrease in plasma TNF- $\alpha$, NO and TBARS compared to the group that received Diclofenac sodium ( $p<$ $0.01)$. Also, supplementation of vitamin $C$ at (1g/k.g.b.w.) resulted in a significant decrease in plasma TNF- $\alpha, \mathrm{NO}$ and TBARS compared to the group that received Diclofenac sodium $(p<0.01)$. Table 3 showed that oral administration of Diclofenac sodium at $150 \mathrm{mg} / \mathrm{kg}$. b. w. resulted in a significant decrease in liver protein thiols (Pr-SHs) and increase liver thiobarbaturic acid reactive substances (TBARS) compared to the normal control group ( $p<0.01)$. Rat receiving extract of any of the two doses of cranberry extract used in this study (75 and $150 \mathrm{mg} / \mathrm{kg}$.b.w.) showed a significant increase in liver protein thiols (Pr-SHs) and decrease liver thiobarbaturic acid reactive substances (TBARS) compared to the group that received Diclofenac sodium $(\mathrm{p}<0.01)$. Also, supplementation of vitamin $\mathrm{C}$ at $(1 \mathrm{~g} / \mathrm{kg}$. b. w.) resulted in a significant increase in liver protein thiols (Pr-SHs) and decrease liver thiobarbaturic acid reactive substances (TBARS) compared to the group that received Diclofenac sodium $(p<0.01)$. Tables 4 and 5 showed that oral administration of Diclofenac sodium at 150 $\mathrm{mg} / \mathrm{kg}$. b. W. resulted in a significant decrease in blood and liver reduced glutathione (GSH) and activities of superoxide dismutase (SOD) and catalase (CAT) compared to the normal control group $(p<0.01)$. Rat receiving extract of any of the two doses of cranberry extract used in this study ( 75 and $150 \mathrm{mg} / \mathrm{kg}$. b.w.) showed a significant increase in blood and liver reduced glutathione (GSH) and activities of superoxide dismutase (SOD) and catalase (CAT) compared to the group that received Diclofenac sodium $(p<0.01)$. Also, supplementation of vitamin $\mathrm{C}$ at (1g/k.g.b.w.) resulted in a significant increase in blood and liver reduced glutathione (GSH) and activities of superoxide dismutase (SOD) and catalase (CAT) compared to the group that received Diclofenac sodium $(p<0.01)$.

Table 6 showed that oral administration of Diclofenac sodium (150mg/kg.b.w.) resulted in a significant increase in plasma total cholesterol (TC), triglycerides (TG) and LDL-C compared to the normal control group $(p<0.01)$. Supplementation of cranberry extract at 75 and $150 \mathrm{mg} / \mathrm{kg}$. b. $\mathrm{w}$. resulted in a significant decrease in 
Table 1: Activity of alanine transaminase (ALT), aspartate transaminase (AST), lactate dehydrogenase (LDH) and alkaline phosphatase (ALP) in plasma of normal and experimental groups of rats.

\begin{tabular}{ccccc}
\hline \multirow{2}{*}{ No. } & \multirow{2}{*}{ Groups } & $\begin{array}{c}\text { ALT } \\
\text { (U/L) }\end{array}$ & $\begin{array}{c}\text { AST } \\
\text { (U/L) }\end{array}$ & $\begin{array}{c}\text { ALP } \\
\text { (U/L) }\end{array}$ \\
\hline \multirow{2}{*}{ (I) } & Normal & 13.76 & 17.52 & 83.48 \\
& $1 \%$ tween 80 & \pm 1.82 & \pm 2.27 & \pm 5.20 \\
& Positive control & 42.60 & 64.00 & 276.54 \\
(II) & Diclofenac sodium & $\pm 4.16^{*}$ & $\pm 5.87^{*}$ & $\pm 11.36^{*}$ \\
& (150 mg/kg.b.w) & 26.08 & 31.25 & 123.28 \\
(III) & Cranberry extract & $\pm 3.06^{*}$ & $\pm 4.45^{*}$ & $\pm 17.64^{*}$ \\
& (75 mg/kg.b.w.) & 15.38 & 18.09 & 97.16 \\
(IV) & Cranberry extract & $\pm 3.21^{*}$ & $\pm 2.07^{*}$ & $\pm 8.15^{*}$ \\
& (150mg/kg b.w.) & 20.11 & 22.36 & 110.90 \\
(V) & Vitamin C & $\pm 2.86^{*}$ & $\pm 3.11^{*}$ & $\pm 7.66^{*}$ \\
\hline
\end{tabular}

Diclofenac sodium was given orally as a daily dose of $150 \mathrm{~m} / \mathrm{kg}$.b.w. It was given to all groups except the normal one. Cranberry extract and vitamin $\mathrm{C}$ were orally given daily for 3 weeks and the last dose of each was given $1 \mathrm{~h}$ before Diclofenac sodium administration. Blood samples were collected $24 \mathrm{~h}$ after Diclofenac sodium administration. Values are given as mean \pm SD for groups of eight animals each. * Significantly different from normal group at $p<0.01$.

Table 2: Level of plasma tumor necroses factor $-\alpha(\mathrm{TNF}-\alpha)$, nitric oxide (NO) and thiobarbaturic acid reactive substances (TBARS) in normal and experimental groups of rats.

\begin{tabular}{ccccc}
\hline No. & Groups & $\begin{array}{c}\text { TNF- } \alpha \\
(\mathrm{Pg} / \mathrm{ml})\end{array}$ & $\begin{array}{c}\text { NO } \\
(\mathrm{Umol} / \mathrm{L})\end{array}$ & $\begin{array}{c}\text { TBARS } \\
\mathrm{nmol} / \mathrm{ml}\end{array}$ \\
\hline \multirow{2}{*}{ (I) } & Normal & 15.68 & 24.11 & 3.49 \\
& $1 \%$ tween 80 & \pm 2.47 & \pm 2.85 & \pm 0.44 \\
(II) & Positive control & 53.14 & 52.28 & 7.20 \\
& Diclofenac sodium & $\pm 4.08^{*}$ & $\pm 5.49^{*}$ & $\pm 1.14^{*}$ \\
(III) & Crangerry extract & 39.40 & 33.73 & 5.28 \\
& (75 mg/kg.b.w.) & $\pm 3.74^{*}$ & $\pm 4.86^{*}$ & $\pm 0.46^{*}$ \\
(IV) & Cranberry extract & 26.55 & 26.50 & 3.84 \\
& (150mg/kg b.w.) & $\pm 2.18^{*}$ & $\pm 3.64^{*}$ & $\pm 0.29^{*}$ \\
(V) & Vitamin C & 35.38 & 32.62 & 4.10 \\
& (1g/kg,b.w) & $\pm 2.07^{*}$ & $\pm 4.00^{*}$ & $\pm 0.35^{*}$ \\
\hline
\end{tabular}

Table 3: Levels of liver protein thiols (Pr-SHs) and thiobarbaturic acid reactive substances (TBARS) in normal and experimental groups of rats.

\begin{tabular}{cccc}
\hline No. & Groups & $\begin{array}{c}\text { TBARS } \\
\text { (nmol/g protein) }\end{array}$ & $\begin{array}{c}\text { Pr-SHs } \\
\text { (nmol/mg protein) }\end{array}$ \\
\hline \multirow{2}{*}{ (I) } & Normal & 1.43 & 136.90 \\
& $1 \%$ tween 80 & \pm 0.17 & \pm 9.63 \\
(II) & Positive control & 3.26 & 67.16 \\
& Diclofenac sodium & $\pm 0.32^{*}$ & $\pm 5.40^{*}$ \\
(III) & (150 mg/kg.b.w) & 1.82 & 102.74 \\
& Cranberry extract & $\pm 0.15^{*}$ & $\pm 7.58^{*}$ \\
(IV) & (75 mg/kg.b.w.) & 1.47 & 127.48 \\
& Cranberry extract & $\pm 0.18^{*}$ & $\pm 9.05^{*}$ \\
(V) & (150mg/kg b.w.) & 1.54 & 115.69 \\
& Vitamin C & $\pm 0.23^{*}$ & $\pm 8.36^{*}$ \\
\hline
\end{tabular}


Table 4: Level of blood reduced glutathione (GSH) and activities of superoxide dismutase (SOD) and catalase (CAT) in normal and experimental groups of rats

\begin{tabular}{ccccc}
\hline No. & Groups & $\begin{array}{c}\text { GSH } \\
(\mathrm{mg} \%)\end{array}$ & $\begin{array}{c}\text { SOD } \\
(\mathrm{U} / \mathrm{gm} \mathrm{Hb})\end{array}$ & $\begin{array}{c}\text { CAT } \\
(\mathrm{U} / \mathrm{gm} \mathrm{Hb})\end{array}$ \\
\hline \multirow{2}{*}{ (I) } & Normal & 23.64 & 385.54 & 95.22 \\
& $1 \%$ tween 80 & \pm 2.83 & \pm 18.65 & \pm 5.84 \\
& Positive control & 8.90 & 167.25 & 48.16 \\
(II) & Diclofenac sodium & $\pm 1.77^{*}$ & $\pm 9.24^{*}$ & $\pm 4.41^{*}$ \\
& (150 mg/kg.b.w) & 15.46 & 304.42 & 73.55 \\
(III) & Cranberry extract & $\pm 2.17^{*}$ & $\pm 11.68^{*}$ & $\pm 4.08^{*}$ \\
& (75 mg/kg.b.w.) & 21.55 & 389.75 & 92.20 \\
(IV) & Cranberry extract & $\pm 3.06^{*}$ & $\pm 21.38^{*}$ & $\pm 4.59^{*}$ \\
& (150mg/kg b.w.) & 19.80 & 360.32 & 80.05 \\
(V) & Vitamin C & $\pm 2.68^{*}$ & $\pm 19.33^{*}$ & $\pm 6.15^{*}$ \\
\hline
\end{tabular}

Table 5: Level of liver reduced glutathione (GSH) and activities of superoxide dismutase (SOD) and catalase (CAT) in normal and experimental groups of rats.

\begin{tabular}{|c|c|c|c|c|}
\hline No. & Groups & $\begin{array}{c}\text { GSH } \\
(\mu \mathrm{g} / \mathrm{mg} \text { of protein })\end{array}$ & $\begin{array}{c}\text { SOD } \\
\text { (U/mg protein) } \\
\end{array}$ & $\begin{array}{c}\text { CAT } \\
\text { (U/mg protein) } \\
\end{array}$ \\
\hline (I) & $\begin{array}{c}\text { Normal } \\
1 \% \text { tween } 80\end{array}$ & $\begin{array}{l}23.48 \\
\pm 2.71\end{array}$ & $\begin{array}{l}27.60 \\
\pm 2.95\end{array}$ & $\begin{array}{l}34.58 \\
\pm 3.21\end{array}$ \\
\hline (II) & $\begin{array}{l}\text { Positive control } \\
\text { Diclofenac sodium } \\
\text { (150 mg/kg.b.w })\end{array}$ & $\begin{array}{c}7.86 \\
\pm 1.08^{*}\end{array}$ & $\begin{array}{c}10.97 \\
\pm 2.71^{*}\end{array}$ & $\begin{array}{c}14.29 \\
\pm 2.07 *\end{array}$ \\
\hline (III) & $\begin{array}{l}\text { Cranberry extract } \\
\text { (75 mg/kg.b.w.) }\end{array}$ & $\begin{array}{c}19.80 \\
\pm 2.25^{*}\end{array}$ & $\begin{array}{c}20.43 \\
\pm 2.00^{*}\end{array}$ & $\begin{array}{c}29.77 \\
\pm 3.44 *\end{array}$ \\
\hline (IV) & $\begin{array}{l}\text { Cranberry extract } \\
(150 \mathrm{mg} / \mathrm{kg} \text { b.w. })\end{array}$ & $\begin{array}{c}22.57 \\
\pm 2.64^{*}\end{array}$ & $\begin{array}{c}27.88 \\
\pm 2.14^{*}\end{array}$ & $\begin{array}{c}35.08 \\
\pm 3.26^{*}\end{array}$ \\
\hline$(\mathrm{V})$ & $\begin{array}{l}\text { Vitamin C } \\
\text { (1g/kg,b.w) }\end{array}$ & $\begin{array}{r}20.97 \\
\pm 3.00^{*} \\
\end{array}$ & $\begin{array}{r}24.09 \\
\pm 3.61^{*} \\
\end{array}$ & $\begin{array}{r}32.16 \\
\pm 3.38^{*} \\
\end{array}$ \\
\hline
\end{tabular}

Table 6: Plasma Level of total cholesterol (TC), triglycerides (TG), HDL-C and LDL-C in normal and experimental groups of rats.

\begin{tabular}{|c|c|c|c|c|c|}
\hline No. & Groups & $\begin{array}{c}\mathrm{TC} \\
(\mathrm{mg} / \mathrm{dl})\end{array}$ & $\begin{array}{c}\mathrm{TG} \\
(\mathrm{mg} / \mathrm{dl})\end{array}$ & $\begin{array}{l}\text { HDL-C } \\
(\mathrm{mg} / \mathrm{dl})\end{array}$ & $\begin{array}{l}\text { LDL-C } \\
(\mathrm{mg} / \mathrm{dl})\end{array}$ \\
\hline (I) & $\begin{array}{c}\text { Normal } \\
1 \% \text { tween } 80\end{array}$ & $\begin{array}{l}190.54 \\
\pm 9.80\end{array}$ & $\begin{array}{l}142.66 \\
\pm 8.64\end{array}$ & $\begin{array}{l}32.17 \\
\pm 3.27\end{array}$ & $\begin{array}{r}128.84 \\
\pm 13.25\end{array}$ \\
\hline (II) & $\begin{array}{l}\text { Positive control } \\
\text { Diclofenac sodium } \\
(150 \mathrm{mg} / \mathrm{kg} . \mathrm{b} . \mathrm{w})\end{array}$ & $\begin{array}{l}248.86 \\
\pm 11.53^{*}\end{array}$ & $\begin{array}{l}205.23 \\
\pm 13.53^{*}\end{array}$ & $\begin{array}{l}26.08 \\
\pm 4.05^{*}\end{array}$ & $\begin{array}{l}181.72 \\
\pm 9.76^{*}\end{array}$ \\
\hline (III) & $\begin{array}{l}\text { Cranberry extract } \\
\text { (75 mg/kg.b.w.) }\end{array}$ & $\begin{array}{c}210.43 \\
\pm 16.54^{*}\end{array}$ & $\begin{array}{r}165.28 \\
\pm 11.87^{*}\end{array}$ & $\begin{array}{l}30.00 \\
\pm 3.68^{*}\end{array}$ & $\begin{array}{r}147.38 \\
\pm 11.94^{*}\end{array}$ \\
\hline (IV) & $\begin{array}{l}\text { Cranberry extract } \\
(150 \mathrm{mg} / \mathrm{kg} \text { b.w.) }\end{array}$ & $\begin{array}{l}195.25 \\
\pm 13.87^{*}\end{array}$ & $\begin{array}{l}140.94 \\
\pm 9.75^{*}\end{array}$ & $\begin{array}{l}34.28 \\
\pm 4.11^{*}\end{array}$ & $\begin{array}{c}132.78 \\
\pm 10.04^{*}\end{array}$ \\
\hline (V) & $\begin{array}{l}\text { Vitamin C } \\
\text { (1g/kg,b.w) }\end{array}$ & $\begin{array}{c}215.77 \\
\pm 12.40^{*}\end{array}$ & $\begin{array}{l}155.18 \\
\pm 11.36^{*}\end{array}$ & $\begin{array}{c}30.85 \\
\pm 3.07^{*}\end{array}$ & $\begin{array}{r}153.89 \\
\pm 13.26^{*}\end{array}$ \\
\hline
\end{tabular}


plasma cholesterol (TC), triglycerides (TG) and LDL-C compared to the group that received Diclofenac sodium $(p<0.05)$. Also, oral administration of Diclofenac sodium resulted in a significant decrease in plasma HDL-C compared to the normal control group $(p<0.01)$. Supplementation of cranberry extract at 75 and $150 \mathrm{mg} / \mathrm{k}$.g.b.w resulted in a significant increase in plasma HDL-C compared to the group that received Diclofenac sodium $(p<$ $0.01)$.

\section{DISCUSSION}

Clinical observations have shown that longterm treatment with diclofenac correlates with the onset or aggravation of congestive heart failure, which can cause serious cardiovascular thromboembolic events, such as myocardial infarction and stroke (Yarishkin et al., 2009).

McGettigan and Henry, (2006), claimed that diclofenac has the highest cardiovascular risk score of the nonselective NSAIDs. This conclusion might be because only diclofenac inhibits L-type $\mathrm{Ca}^{2+}$ channels and the $\mathrm{Na}^{+}$current in cardiomyocytes (Yarishkin et al., 2009).

Antioxidants are the first source of protection of the body against free radicals and other oxidants, being the compounds that the attack and the formation of radical species within cells. The group of antioxidants inside the organism is known as the total antioxidant state (TAS) Teixeira et al., (2013).

The current study revealed that both repeated doses of diclofenac sodium $(150 \mathrm{mg} / \mathrm{kg}$. b.w.) induced liver toxicity as indicated by elevations in plasma liver damage markers, namely ALT, AST and ALP compared with normal animals. Hepatotoxicity from NSAIDs can occur within 28 days of therapy after drug administration29. The possible mechanism of Diclofeac induced liver injury is due to hypersensitivity and metabolic aberration which can produce serious liver damage in human and experimental animals with toxic doses (Hamza, 2007).

Antioxidant effect is a well-established function of cranberry or flavonoids found in the cranberry (Côté et al., 2010). In addition, cranberry procyanidins have been found to scavenge reactive carbonyls by formation of adducts (Liu et al., 2011), and the current study demonstrated elevation of plasma protein and albumin in Diclofenac sodium treated animals. The antiinflammatory properties of cranberry are in fact due to its proanthocyanidin content, which heals the mucosal surfaces lesions induced by Diclofenac sodium (Howell et al., 2001) and elevation of food intake and absorption.

The significant increase in level of plasma TNF- $\alpha$, NO and TBARS in diclofenactreated groups indicates ongoing peroxidative stress and compromised antioxidant defense mechanisms. Hickey et al., (2001) reported that diclofenac has the ability to provoke massive oxidative stress in vivo. The mechanism of diclofenac-induced mitochondrial injury seems to involve generation of ROS, causing oxidative stress to hepatocytes as proposed by (Sokol et al., 2011) and number of structurally related NSAIDs do produce oxidative stress and the underlying mechanisms have been suggested to be based on peroxidase-catalyzed production of NSAID radicals, which in turn can oxidize GSH and NAD(P)H. NSAID radicals can undergo redox cycling.

In other systems, gastric mucosa lesions is elevated by extracellular TNF- $\alpha$ and NO (Eissner et al., 1995), in particular, has been shown to cause acute cell death in a variety of in vitro and in vivo conditions (Salvesen and Dixit, 1997). the finding that Diclofenac sodium administration results in a rapid increase in TNF- $\alpha$ and NO plasma levels (Appleyard et al., 1996) and that inhibition of TNF- $\alpha$ synthesis and release protects from NSAID-induced gastropathy (Fiorucci et al., 1997) suggests that this 
cytokine plays a major role in mediating gastric mucosal injury in NSAID-treated rats. However, because NSAIDs stimulate TNF- $\alpha$ and NO release (present results), their site of action must be located downstream to this cytokine.

Lipid peroxide mediated tissue damage has been observed in DIC treated rats. It has been observed that DIC administration is associated with lipoxygenase-derived peroxides (Boshra and Hussein, 2014). The increased lipid peroxidation in the DICtreated animals may be due to the observed remarkable increase in the concentration of TBARS and HP (lipid peroxidative markers) in the liver and kidney (AbdelMaksoud et al., 2015).

Hussein, (2012) has reported that the concentration of lipid peroxides increases in the tissues of DIC-treated rats. In the present study, TBARS level in liver and kidney were significantly lower in the cranberry -treated groups compared to the DIC-treated control group. The present results were confirmed with (AbdelMaksoud et al., 2015).

The current study showed that either repeated low or high dose of diclofenac induced oxidative stress in cardiac tissues of rats as evidenced by significant reduction in the activities of reduced glutathione (GSH) metabolizing enzymes, SOD as well as CAT in cardiac tissues of diclofenac intoxicated rats versus normal healthy ones.

This effect was a dose dependent and may consider one of the diclofenac mechanisms induced liver toxicity. GR is the key enzyme in the conversion of oxidized glutathione (GSSG) back to the reduced form (GSH).

GSH, a non-enzymatic antioxidant, has an important role in scavenging the electrophilic moieties produced by toxic chemicals and conjugate them to less toxic products (Ding, 2012). CAT is an antioxidant enzyme widely distributed in all animal tissues. It decomposes hydrogen peroxide and protects the tissue from highly reactive hydroxyl radicals (Ding, 2012). Thus the less amount of GSH production due to inhibition of its metabolizing enzymes together with reduction of CAT activity in cardiac of diclofenac intoxicated rats may reduce the capacity of the tissue to protect itself from the diclofenac induced oxidative tissue damage. Our result is supported by some authors who stated the reduction in the levels of hepatic and renal enzymatic and non-enzymatic antioxidants of animals injected with Diclofenac (Baravaliaetal., 2011 and Mehtaet al., 2008).

Since cranberry has shown antioxidant and free radical scavenging activity (Sies, 1997), the present study primarily ameliorating the effect of cranberry' polyphenols on iron accumulation and oxidative damage in the liver of iron overloaded rat is studied. Oral administration of cranberry extract significantly inverse the Diclofenac sodium induced peroxidative damage in liver which is evidenced from the lowered levels of thiobarbituric acid reactive substances and lipid hydroperoxides.

This may be due to the antioxidative effect of polyphenols (Veerappan et al., 2004). An antioxidant is a molecule capable of slowing or preventing the oxidation of other molecules. Oxidation is a chemical reaction that transfers electrons from a substance to an oxidizing agent. Diclofenac sodium induces cellular injury and functional abnormalities in hepatocytes by the process of lipid peroxidation (Hussein, 2012). Because the liver has a central role in the maintenance of lipid homeostasis, excess iron may alter the concentration of serum lipids, which could reduce or increase the risk of atherosclerosis.

Lipid peroxidation may also damage membranes in other cells, altering important elements of control for blood pressure and liver rate. Given that increased LDL cholesterol (LDL-C) and decreased HDL cholesterol (HDL-C). Both Brunet et al. 
(1999) and Britton et al. (1987) found the same results.

In line with other NSAID, the current study demonstrated that injection of rats with either low or high repeated dose of diclofenac caused hyperglycemia and hyperlipidemia which represented by marked increase in serum glucose and lipid profiles including TG, TCh and LDL-C with a concomitant decreased in HDL-C in relation to control ones (Abdel Aziz, 2001).

This metabolic disorder induced by the used drug was severe in rats injected with high diclofenac repeated dose. The increase in serum glucose in diclofenac treated rats may be reflected that the drug either affected the insulin receptors due to its cytotoxicity and/or it has damaging impact on pancreas. The latter suggestion is supported by previous studies reported that treatment with diclofenac was associated with acute pancreatitis (Khan and Edward 1993) which is the major cause of impaired glucose metabolism and hyperglycemia (Vlasakova et al., 2002).

However, hyperlipidemia induced by diclofenac injection may be explained on the basis that enhancement of lipolysis by diclofenac, leading to increased concentration of plasma free fatty acids (Zanaboni, and Fasoli, 1981). The stimulating effect of diclofenac on lipolysis may related to its potent inhibitory effect on prostaglandins synthesis that are involved in the feed-back regulation of lipolysis, and mediate the inhibitory effect on lipolysis of lipoprotein lipase activity (Axelrod, 1992).

From the obtained results it could be concluded that cranberry extract was an effective in protection against liver toxicity induced by Diclofenac sodium in rats. Cranberry extract received the highest oxygen radical absorbing capacity (ORAC) value and exhibited superior antioxidant properties and it was able to ameliorate plasma oxidative stress biomarkers as well as enzymatic and non-enzymatic antioxidant defense system in liver tissue.

\section{REFERENCES}

Abdel Aziz, I.S. 2001. Effect of Indomethacin suppository on serum glucose, some lipids, non-protein nitrogen constituents and rectal mucosa of rabbit. AnNajahUniv J Res 15:1-14.

Abdel-Maksoud, H.A., Hussein, M.A., Barakat, M. 2015. Cranberry extract as a functional food in treatment of myocardial toxicity induced by nicotine in Rats. (5)4: 1174-1180

Allain, C.C., Poon, L.S., Chan, C.S., 1974. Enzymatic determination of total serum cholesterol. ClinChem. 4: 470-475.

Appleyard, C.B., McCafferty, D.M., Tigle, A.W., Swain, G., Wallace, J.L. 1996. Tumor necrosis factor mediation of NSAID-induced gastric damage: role of leuKocyte adherence. Am J Physiol 270: $42-48$.

Axelrod, L. 1992. Coordinate control of lipolysis by prostaglandin E2 and prostacyclin in rat adipose tissue. Diabetes 41: 927-935.

Baravalia, Y., Vaghasiya, Y., Chanda, S. 2011. Hepatoprotective effect of WoodfordiafruticosaKurz flowers on diclofenac sodium induced liver toxicity in rats. Asian Pacific JTropical Med 4: 342-346.

Beyaert, R., Fiers, W. 1998. Tumor Necrosis Factor and Lymphotoxin. In Cytokines, A.R.M.-S. a. R. Thorpe, eds. Academic Press, San Diego,. 335-360.

Boshra, S.A., Hussein, M.A. 2014. The protective role of Colchicine on Diclofenac sodium induced hepato-renal toxicity in albino rats model. International Journal of Pharmaceutical Sciences and Research. 12: 5136-5144.

Britton, R.S., Bacon, B.R., Recknagel, R.O. 1987. Lipid peroxidation and associated hepatic organelle dysfunction in iron overload. Chem. Phys. Lipids 45: 207239.

Brunet, S., Thibault, L., Delvin, E., Yotov, W., Bendayan, M., Levy, E. 1999. Dietary iron overload and induced lipid peroxidation are associated with impaired plasma lipid transport and hepatic sterol metabolism in rats. Hepatology 29: 1809 -1817 . 
Burnstein, M., Selvenick, H.R., Morfin, R. 1970. Rapid method for isolation of lipoprotein from human serum with polyanions. J Lipid Res., 11: 583- 395.

Cantoni, L., Valaperta, R., Ponsoda, X., Castell, J.V., Barelli, D., Rizzardini, M. 2003. Induction of hepatic hemoxygenase- 1 by diclofenac in rodents: role of oxidative stress and cytochrome P-450 activity. Hepatology. 38: 776-783.

Chanarin, I. 1989. Text book of Laboratory Haematology: An Account of Laboratory techniques, Churchill Livingstone, New York PP. 107.

Côté, J., Caillet, S., Doyon, G., Sylvain, J.F., Lacroix, M. 2010. Bioactive compounds in cranberries and their biological properties. Crit Rev Food SciNutr. 50: 666-679.

Ding, G. 2012. Cardioprotection from oxidative stress in the newborn heart by activation of PPAR $\gamma$ is mediated by catalase. Free RadicBiol Med 53: 208-215.

Eissner, G., Flohlhuber, F., Grell, M., 1995. Critical involvement of transmembrane tumor necrosis factor in endothelial programmed cell death mediated by ionizing radiation and bacterial endotoxin. Blood 86: A4184.

Fiorucci, S., Santucci, L., Gerli, R. 1997. NSAIDs upregulate $\quad \beta 2$-integrin expression on human neutrophils through a calcium- dependent pathway. Aliment PharmacolTher. 11: 671-80.

Fossati, P., Prencipe, L. 1982. Serum triacylglycerols determined calorimetrically with an enzyme that produces hydrogen peroxide. Clin Chem. 1: 2077-2080.

Friedewald, W.T. 1972. Estimation of concentration of low-density lipoprotein cholesterol in plasma without use of the preparative ultracentrifuge. Clin Chem. 18: 499-502.

Gomez-Lechon, M.J., Ponsoda, X.O.C.E., Donato, T., Castell, J.V., Jover, R. 2003. Diclofenac induce apoptosis in hepatocytes by alteration of mitochondrial function and generation of ROS. BiochemPharmacol 66: 2155 2167.

Hamza, A.A. 2007. Curcuma longa, Glycyrrhizaglabra and Moringaoleifera ameliorate diclofenac- induced hepatotoxicity in rats, Am J PharmacolToxicol 2: 80-88.

Howell, A.B., Leahy, M., Kurosawa, E., Guthrie, N. 2001. In vivo evidence that cranberry proanthocyanidins inhibit adherence of p-fimbriated E. coli bacteria to uroepithelial cells. Federation of American Societies for Experimental Biology Journal 15: A284.

Hussein, M.A., Abdel-Khalek, N.G., El Bishbishy, M.H. 2014. Composition, in vitro antioxidant and antitumor properties of essential oil from the seeds of Moringaoleifera. International Journal of Pharma Sciences, 3: 532-540.

Khan, I.H., Edward, N. 1993. Pancreatitis associated with diclofenac. Postgrad Med J 69: 486-487.

Kind, P.R.N., King, E.J. 1954. Estimation of plasma phosphatase by determ-ination of hydrolysed phenol with aminoantipyrine. J. Clin. Pathol, 7: $322-326$.

Koster, J.F., Biemond, P., Swaak, A.J.G. 1986. Intracellular and extracellular sulphydryl levels in rheumatoid arthritis. Ann. Rheum. Dis., 45: $44-46$.

Luo, Z., Harada. T., London, S.,Gajdusek, C., Mayberg, M. 1995. Antioxidant and iron chelating agents in cerebral vasospasm, Neurosurgery. 37: 1054.

Manach, C., Scalbert, A., Morand, C. 2004. Polyphenols: Food sources and bioavailability. Am J ClinNutr., 79: 72747.

Marklund, S., Marklund, D. 1974. Involvement of the superoxide anion radical in the autoxidation of pyrogallol and a convenient assay for superoxide dismutase. Eur. J. Biochem., 47: 469.

McGettigan, P., Henry, D. 2006. Cardiovascular risk and inhibition of cyclooxygenase: a systematic review of the observational studies of selective and nonselective inhibitors of cyclooxygenase 2. 4, 296(13): 1633-44.

Mehta, R., Shang, Arin and O’brien, P.J. 2008. Preventing cell death induced by carbonyl stress, oxidative stress or mitochondrial toxins with vitamin B antiAGE agents.MolNutr Food Res 52: 379385.

Miranda, K.M., Espey, M.G., Wink, D.A. 2001. A rapid, simple spectrophotometric method for simultaneous detection of nitrate and nitrite. Nitric Oxide. 5: 62-71. 
Mullen, W., Marks, S.C., Crozier, A. 2007. Evaluation of phenolic compounds in commercial fruit juices and fruit drinks. J Agric Food Chem.; 55: 3148-57.

Nichans, W.H., Samulelson, B. 1968. Formation of malondialdehyde from phospholipid arachidonate during microsomal lipid peroxidation. Eur J Biochem, 6: 126-30.

Reitman, S., Frankel, S.A. 1957. Colorimetric method for the determination of serum oxaloacetic acid and glutamic pyruvic transaminases. Am. j. Clin. Pathol., 28: $56-63$

Salvesen, G.S., Dixit, V.M. 1997. Caspases: Intracellular signaling by proteolysis. Cell 91: 443-6.

Sies, H. 1997. Oxidative stress, oxidants and antioxidants, Exp. Physiol. 82: 291-295.

Sinha, A.K. 1972. Colorimetric assay of catalase. J. Anal Biochem. 47 (2): 389-94.

Sokol, R.J., Straka, M.S., Daha, R., Devereaux, M.W., Yerushalmi, B., Gumpricht, E., 2001. Role of oxidant stress in the permeability transition induced in rat hepatic mitochondria by hydrophobic bile acid. Pediatric Res.49:519-31.

SPSS (2012). (SPSS 15, Inc., Chicago, IL, USA).

Teixeira, V., Valente, H., Casal, S. 2013. Blood antioxidant and oxidative stress biomarkers acute responses to a $1000-\mathrm{m}$ kayak sprint in elite male kayakers. J Sports Med physical fitness; 53(1): 7179.

Veerappan, R.M., Senthil, S., Rao, M., Ravikumar, M. 2004. Redox status and lipid peroxidation in alcoholic hypertensive patients and alcoholic hypertensive patients with diabetes, Clin. Chem. Acta 340: 207-212.

Vlasakova, Z., Bartos, V., Spicak, J. 2002. Diabetes mellitus in chronic pancreatitis and insulin sensitivity. VnitrLek 48: 878881.

Vvedenskaya, I.O., Rosen, R.T., Guido, J.E., 2004. Characterization of flavonols in cranberry (Vacciniummacrocarpon) powder. J Agric Food Chem., 52: 188-95.

Wallace, J.L., McKnight, W., Reuter, B.K., Vergnolle, N. 2000. NSAID-induced gastric damage in rats: requirement for inhibition of both cyclooxygenase 1 and 2. Gastroent. 119: 706-714.

Weichselbaum, T.E. 1946. An accurate and rapid method for the determination of proteins in small amounts of blood, serum and plasma. Am. J. Clin. Pathol. 16: 4049.

Yarishkin, O.V., Hwan,g E.M., Kim, D., Yoo, J.C., Kang, S.S., Kim, D.R., Shin, J.H., Chung, H.J., Jeong, H.S., Kang, D., Han, J., Park, J.Y., Hong, S.G. 2009. Diclofenac, a Non-steroidal Antiinflammatory Drug, Inhibits L-type Ca Channels in Neonatal Rat Ventricular Cardiomyocytes. Korean J PhysiolPharmacol. 13(6): 437-42.

Zanaboni, L., Fasoli, A. 1981. Influence of two nonsteroidal anti-inflammatory drugs on lipolysis and on lipolysis and on plasma post-heparin lipoprotein lipase activity in normal man Eur J ClinPharmacol 20: 263-267. 